\title{
Laboratory assessment of the antimycotic drug clotrimazole
}

\author{
R. J. HOLT AND R. L. NEWMAN ${ }^{1}$ \\ From the Group Laboratories, Queen Mary's Hospital for Children, Carshalton, Surrey
}

SYNOPSIS Laboratory studies on clotrimazole showed that it had marked activity in vitro against all the Candida spp. and Cryptococcus spp. tested, against almost all strains of dermatophytes, and against Aspergillus spp and other fungal genera responsible for systemic mycoses; it had limited activity towards Gram-positive bacteria. The majority of Candida strains required MICs below $1 \mu \mathrm{g} / \mathrm{ml}$ and MCCs below $2 \mu \mathrm{g} / \mathrm{ml}$.

Serum, urine, and faecal assays of clotrimazole were made by microbiological methods on five children who received $100 \mathrm{mg} / \mathrm{kg} /$ day clotrimazole for several weeks. In-vitro sensitivity tests and biological fluid drug assays are also reported on specimens from 18 patients in other hospitals receiving clotrimazole for severe candidosis; several were renal transplant cases. Similar investigations are reported on specimens from 18 patients with pulmonary aspergilloses.

The significance of low levels of the drug in body fluids, even after prolonged therapy, is discussed, and it is suggested that clotrimazole may be the first of a long series of imidazole derivatives with varying pharmacological and therapeutic properties.

Until recently the only available therapy for most systemic fungal infections has been with the polyene antibiotics-nystatin, pimaricin, candicidin, and amphotericin $B$. The first three cannot be administered parenterally, and they are not absorbed from the bowel; occasional success when given orally for urinary, pulmonary, and systemic candidoses has probably been due to the eventual elimination of the faecal reservoir. The problem in treating systemic fungus infections arises from the difficulty in achieving an effective serum drug level; amphotericin B can be administered systemically to give good levels but may have severe toxic effects (Andriole and Kravetz, 1962).

Laboratory and clinical reports by Plempel, Bartmann, Bŭchel, and Regel (1969); Oberste-Lehn, Baggesen,and Plempel(1969) on the antifungal activity of a new synthetic drug, Bay b, 5097, Clotrimazole, and the good results reported by Marget and Adam (1971) in childhood candidosis have prompted further laboratory and clinical studies, some of which are reported in this paper.

\footnotetext{
${ }^{1}$ Since this paper was written R. L. Newman has died.
}

Received for publication 12 October 1972.

\section{Methods and Materials}

Clotrimazole is a trityl imidazole derivative-bisphenyl ( 2 chlorphenyl)-1-imidazolyl-methane (Fig. 1). A fluffy white powder, insoluble in water, it dissolved freely in organic solvents; a $1 \%$ solution in chloroform, stored in the dark at $4^{\circ} \mathrm{C}$, was used as stock. Assays against freshly prepared standards, diluted in $0.01 \mathrm{M}$ phosphate buffer at $p \mathrm{H} \mathrm{7.2,} \mathrm{showed}$

$$
\text { BAY b } 5097 \text { 'CLOTRTMAZOLE' }
$$

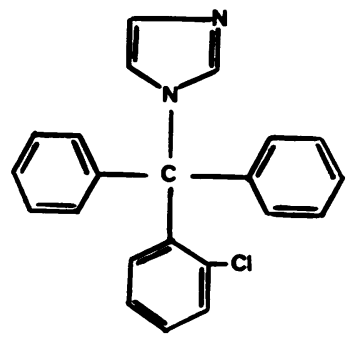

bis-phenyl (2-chlorphenyl -l-imidazolyl-methane

Fig. 1 Structoral formula for clotrimazole. 
no loss of potency over a period of several months. Alternatively, a $1 \%$ solution in polyethylene glycol is available (Bayer AG) and dilutions from this gave consistent results on repeated testing. Dilutions from both stock solutions into aqueous vehicles become opalescent immediately on addition, as do the waterinsoluble polyene antibiotics, but appear to retain full activity.

Candida and fungi were isolated from clinical specimens by the methods reported earlier (Holt and Newman, 1967); Czapek Dox agar or Sabouraud glucose peptone agar to which was added $100 \mu \mathrm{g} / \mathrm{ml}$ of chloramphenicol or, more recently, gentamicin, proved satisfactory for the recovery of these organisms from specimens initially contaminated with large numbers of bacteria.

Candida isolates were routinely differentiated into Candida albicans and non-albicans by the serum germ tube and chlamydospore production tests; species identification of candida strains and of systemic fungi were kindly carried out by Dr I. G. Murray and Miss C. Philpott (Mycology Reference Laboratory, London) who also supplied many other fungi for sensitivity testing. Sensitivity testing was performed as soon as possible after primary isolation. The same workers kindly tested sera from the cases reported here for immune antibodies.

\section{Administration of the Drug}

Adults and babies received $100 / \mathrm{kg} /$ day in four sixhourly oral doses; capsules each containing $0.5 \mathrm{~g}$ clotrimazole were easily swallowed by adults. These capsules were too large for small babies, and an aqueous suspension of the compound was therefore prepared to contain the calculated six-hourly dose in 1 or $2 \mathrm{ml}$, measured by the nursing staff from $2 \mathrm{ml}$ syringes. The suspension settled rapidly after mixing, although separation was retarded by the addition of $0.2 \%$ gum tragacanth; it was stored at $4^{\circ}$ and assays showed no loss of potency after 14 days, the maximum time for which the preparation was stored on the ward.

\section{Sensitivity Tests}

BY DISC

Filter paper discs, $9 \mathrm{~mm}$, were impregnated with clotrimazole suspension and rapidly vacuum dried. A $300 \mu \mathrm{g} / \mathrm{ml}$ suspension of clotrimazole in $0.01 \mathrm{M}$ phosphate buffer at $p \mathrm{H} 7.2$ was diluted from the $1 \%$ stock solution in polyethylene glycol; the discs were sterilized in dry air at $160^{\circ}$ for one $\mathrm{hr}$, and 1 drop from a $30 \mathrm{drop} / \mathrm{ml}$ pipette was placed onto each. The batch of impregnated discs was immediately vacuum-dried at room temperature over silica gel and stored in tightly capped containers at $4^{\circ}$. Assays showed that no deterioration occurred under these conditions after three months' storage.

A suspension of Candida or Cryptococcus sp to be tested was made in infusion broth to an approximate density of $1 \times 10^{5}$ cells per ml. An even lawn of this suspension was sown over an infusion broth agar

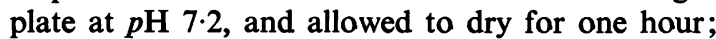
clotrimazole discs were then planted onto the agar surface and the plate was incubated for 24 to 48 hours. The diameter of the zone of inhibition was measured; organisms giving zones greater than $20 \mathrm{~mm}$ diameter were deemed to be fully sensitive; zones between 12 and $20 \mathrm{~mm}$ to indicate relative sensitivity; and less than $12 \mathrm{~mm}$ as relatively to fully resistant to clotrimazole. Counted suspensions of mycelating fungi were not feasible, so a very light, well mixed inoculum was prepared; the zones of inhibition were less well defined with these fungi, but still gave reasonable indications of sensitivity to the drug.

Correlation between agar diffusion sensitivity tests by disc and liquid minimal inhibitory concentration (MIC) tests was attempted for suspensions of $C$. albicans at the stated density, and was as follows:

\begin{tabular}{ll}
\hline $\begin{array}{l}\text { Disc Zone of Inhibition } \\
(\mathrm{mm})\end{array}$ & $\begin{array}{l}M I C \\
(\mu \mathrm{g} / \mathrm{ml})\end{array}$ \\
\hline$>20$ & $<0 \cdot 2$ \\
$20-12$ & $0 \cdot 2-2 \cdot 0$ \\
$<12$ & $>2$ \\
\hline
\end{tabular}

ESTIMATION OF MINIMAL INHIBITORY AND MINIMAL CIDAL CONCENTRATION (MIC AND MCC)

Preliminary studies showed that there appeared to be no differences between the MIC/MCC of clotrimazole for fungi when tested at $p \mathrm{H} 5 \cdot 0,6 \cdot 0,7 \cdot 0$, and 8.0; all estimations, and all assays, were therefore performed at $p \mathbf{H} 7 \cdot 2$ as a biological reality. Similarly a few MIC/MCC estimations for fungi of clinical interest showed no significant differences when performed at $22^{\circ}, 26^{\circ}$, and $37^{\circ} ; 37^{\circ}$ was selected as standard, since this was the temperature at which the drug would be likely to encounter systemic fungi clinically.

Infusion broth or peptone water (Cruickshank, 1965) was used in all experiments; the use of a medium reinforced with carbohydrate was avoided because fermentation with acid products might lower the $p \mathrm{H}$ well below 5.0 and tend to reduce the drug's activity.

Drug concentrations in the range $0.05-20 \mu \mathrm{g} / \mathrm{ml}$ were made in $2 \mathrm{ml}$ lots of medium, and 1 drop of standard inoculum was added to each. In the case of 
Candida, Cryptococcus, Torulopsis, and Geotrichum strains this inoculum was established by direct counts on 48-hr broth cultures in a haemocytometer chamber, and was calculated to give an initial inoculum of $1 \times 10^{5} \mathrm{cells} / \mathrm{ml}$. A non-ionic surfactant, Triton $\mathrm{X100}$, at $\mathbf{0 . 1 \%}$ was used to disperse cell aggregates in both counting and seeding (Holt, 1971). Such accurate inocula were not possible with actively mycelating fungi, particularly those forming tough pellicles on the broth surface; attempts were therefore made to prepare a suspension of even turbidity by shaking with sterile glass beads or fragmented glass and a light inoculum was added to each tube, consisting usually of one drop of a 1 in 100 dilution of a well dispersed 48 -hr broth culture. The MIC was noted after two and four days at $37^{\circ}$, and the MCC estimated by subculturing into infusion broth from all tubes showing no growth and by planting standard drops onto infusion or Sabouraud agar. In most cases the residuum of the initial inoculum could be seen; this was washed three times with sterile water or infusion broth before subculturing to remove any drug still adherent to the fundal structure. Unpublished observations during work with the halogenated oxyquinolines had suggested that antifungal drugs might otherwise be carried over into subcultures and thus give a fallaciously low MCC.

Sensitivity to clotrimazole was also estimated by the agar dilution technique; light inocula of the fungus were spotted onto a series of infusion agar plates containing different drug concentrations. The end point after two to three days at $37^{\circ}$ indicated the MIC; the MCC of the drug was estimated by pad replicating the inoculum site after incubation onto drug-free nutrient agar. The results obtained by this method compared well with those from the liquid methods detailed above.

DETECTION OF EMERGENT RESISTANT MUTANTS Light inocula of representative strains of each fungal genus were successively passaged across increasing drug gradients on agar layer plates (Szybalski, 1952). In most cases it was necessary to start on plates with a gradient $0-0.5 \mu \mathrm{g} / \mathrm{ml}$; two to three days were allowed for growth on each plate, and subcultures were taken from the growth edge farthest across the drug gradient. This was continued for 10 to 15 passages, and liquid MICs on the most resistant growth were compared with the values obtained with the original strains before the sequence was started.

EFFECT OF CLOTRIMAZOLE ON MORPHOLOGY OF FUNG I

Candida, Aspergillus, and Trichophyton species were grown in broth containing levels of drug previously established as subinhibitory for the individual strain. After three to five days, very thin wet preparations were examined by interference microscopy at $\times 150$ and $\times 600$ magnification.

\section{ASSAY OF CLOTRIMAZOLE IN BIOLOGICAL} FLUIDS

Infusion agar or any of the proprietary penicillin assay agars proved satisfactory at $p H \mathbf{H} \cdot 2$. More than 100 strains of Saccharomyces and Candida were tested as possible indicator organisms, and a strain of Candida pseudotropicalis (Carshalton) was selected; it required an MIC of below $0.01 \mu \mathrm{g} / \mathrm{ml}$ clotrimazole, and appeared to be stable after some 100 weekly subcultures. An overnight culture in infusion broth, checked for purity by plate-out when initially inoculated, was used as inoculum. Polystyrene plates, $14 \mathrm{~cm}$ diameter, were placed on level surfaces and $50 \mathrm{ml}$ agar base was poured. When set, the base was overlaid with $20 \mathrm{ml}$ agar seeded with $0.1 \mathrm{ml}$ of the overnight broth culture, and the plates were thoroughly dried for two hr at $37^{\circ}$. For larger batches of assays $25 \times 25 \mathrm{~cm}$ assay plates were used (Mast); they required $200 \mathrm{ml}$ base and $80 \mathrm{ml}$ seeded overlay.

The range of standards was $0.02,0 \cdot 1,0.5,2 \cdot 0$, and $10.0 \mu \mathrm{g} / \mathrm{ml}$ clotrimazole, diluted in $90 \%$ serum or in

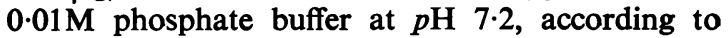
which biological fluids were being assayed. Preliminary studies showed no difference between $90 \%$ serum, $50 \%$ serum, and aqueous buffer standards; this appears to indicate that no in vitro binding occurred in serum, and during the past year aqueous buffer standards at $p \mathrm{H} \mathbf{7 \cdot 2}$ were therefore used for all assays.

Fish spine beads (no. 3 size) were used as assay reservoirs in the way detailed by Lightbown and Sulitzeanu (1957). After two hr prediffusion at $20^{\circ}$, plates were incubated on a level surface for $24 \mathrm{hr}$ at $37^{\circ}$; the zones of inhibition were of good size, about $30 \mathrm{~mm}$ diameter round the $2 \mu \mathrm{g} / \mathrm{ml}$ standard, showing a well defined outer margin of inhibition, with hazy growth perhaps $2 \mathrm{~mm}$ wide inside this margin. The outer margin was measured in all cases, the mean of two diameters of each zone being used for subsequent plots on half-log graph paper.

\section{Results}

SENSITIVITY OF CLINICAL ISOLATES OF FUNGI TO CLOTRIMAZOLE

These results are shown in Tables I, II, and III.

SENSITIVITY OF GRAM-POSITIVE AND GRAMNEGATIVE BACTERIA TO CLOTRIMAZOLE These changes are shown in Table IV. 
Table I Sensitivity of clinical isolates of yeast-like fungi to clotrimazole

\begin{tabular}{|c|c|c|c|c|c|c|c|}
\hline & \multirow{2}{*}{$\begin{array}{l}\text { Total } \\
\text { Tested }\end{array}$} & & \multicolumn{5}{|c|}{ Concentration of Clotrimazole $(\mu \mathrm{g} / \mathrm{ml})$} \\
\hline & & & $<0 \cdot 1$ & $0 \cdot 1-0 \cdot 5$ & $0 \cdot 5-2$ & $2-10$ & $>10$ \\
\hline Epidermophyton floccosum & 5 & $\begin{array}{l}\text { MIC } \\
\text { MCC }\end{array}$ & & 4 & $\begin{array}{l}1 \\
5\end{array}$ & & \\
\hline Microsporum audouini & 4 & MIC & & 4 & & & \\
\hline Microsporum canis & 4 & $\begin{array}{l}\text { MIC } \\
\text { MCC }\end{array}$ & & $\begin{array}{l}2 \\
1\end{array}$ & $\begin{array}{l}4 \\
2 \\
3\end{array}$ & & \\
\hline Microsporum gypseum & 2 & $\begin{array}{l}\text { MIC } \\
\text { MCC }\end{array}$ & & & 2 & 2 & \\
\hline $\begin{array}{l}\text { Trichophyton mentagrophytes } \\
\text { (including integumentum) }\end{array}$ & 5 & $\begin{array}{l}\text { MIC } \\
\text { MCC }\end{array}$ & & $\begin{array}{l}2 \\
1\end{array}$ & $\begin{array}{l}3 \\
4\end{array}$ & & \\
\hline Trichophyton rubrum & 3 & $\begin{array}{l}\text { MIC } \\
\text { MCC }\end{array}$ & & 1 & $\begin{array}{l}2 \\
3\end{array}$ & & \\
\hline Trichophyton sulphureum & 4 & $\begin{array}{l}\text { MIC } \\
\text { MCC }\end{array}$ & & 2 & $\begin{array}{l}2 \\
2\end{array}$ & 2 & \\
\hline Trichophyton verrucosum & 2 & $\begin{array}{l}\text { MIC } \\
\text { MCC }\end{array}$ & & $\begin{array}{l}2 \\
2\end{array}$ & & & \\
\hline Trichophyton violaceum & 3 & $\begin{array}{l}\text { MIC } \\
\text { MCC }\end{array}$ & & 2 & $\begin{array}{l}1 \\
3\end{array}$ & & \\
\hline
\end{tabular}

Table II Sensitivity of dermatophytes to clotrimazole

\begin{tabular}{|c|c|c|c|c|c|c|c|}
\hline & \multirow{2}{*}{$\begin{array}{l}\text { Total } \\
\text { Tested }\end{array}$} & & \multicolumn{5}{|c|}{ Concentration of Clotrimazole $(\mu \mathrm{g} / \mathrm{ml})$} \\
\hline & & & $<0.1$ & $0 \cdot 1-0 \cdot 5$ & $0.5-2$ & $2-10$ & $>10$ \\
\hline Aspergillus flavus & 3 & $\begin{array}{l}\text { MIC } \\
\text { MCC }\end{array}$ & & & 3 & 3 & \\
\hline Aspergillus fumigatus & 18 & MIC & & 8 & & 1 & \\
\hline Aspergillus niger & 3 & $\begin{array}{l}\text { MCC } \\
\text { MIC } \\
\text { MCC }\end{array}$ & & & $\begin{array}{l}9 \\
2\end{array}$ & $\begin{array}{l}8 \\
1 \\
3\end{array}$ & 1 \\
\hline Allescheria boydii & 2 & $\begin{array}{l}\text { MIC } \\
\text { MCC }\end{array}$ & & & 2 & 2 & \\
\hline Madurella mycetomi & 2 & $\begin{array}{l}\text { MIC } \\
\text { MCC }\end{array}$ & & & 2 & 2 & \\
\hline Mucor mucedo & 2 & $\begin{array}{l}\text { MIC } \\
\text { MCC }\end{array}$ & & 1 & $\begin{array}{l}1 \\
2\end{array}$ & & \\
\hline Sporotrichum schenkii & 3 & $\begin{array}{l}\text { MIC } \\
\text { MCC }\end{array}$ & & & 1 & $\begin{array}{l}2 \\
2\end{array}$ & 1 \\
\hline
\end{tabular}

Table III Sensitivity to clotrimazole of other fungi of medical interest 


\begin{tabular}{|c|c|c|c|c|c|c|c|}
\hline \multirow{2}{*}{$\begin{array}{l}\text { Organisms } \\
\text { (all current clinical isolates) }\end{array}$} & \multirow{2}{*}{$\begin{array}{l}\text { No. } \\
\text { Tested }\end{array}$} & \multicolumn{3}{|c|}{ Disc Sensitivity ${ }^{1}$ of Strains Sensitive to ( $\mu g /$ disc) } & \multirow{2}{*}{$\begin{array}{l}\text { No. } \\
\text { Tested }\end{array}$} & \multicolumn{2}{|c|}{ Liquid Sensitivity $(\mu \mathrm{g} / \mathrm{ml})$} \\
\hline & & 10 & 50 & 200 & & $\begin{array}{l}\text { MIC } \\
\text { Concentration }\end{array}$ & $\begin{array}{l}\text { MCC } \\
\text { Concentration }\end{array}$ \\
\hline \multicolumn{8}{|l|}{ Gram-positive } \\
\hline Staphylococcus aureus & 38 & 2 & 38 & 38 & 2 & \multirow{4}{*}{$\begin{aligned} & 10 \\
& 50 \\
&<\quad 5 \\
&> 50 \\
&> 500 \\
&> 500 \\
& 200-500 \\
& 200-500\end{aligned}$} & \multirow{4}{*}{$\begin{aligned} & 10 \\
> & 50 \\
& 10-20 \\
> & 50 \\
> & 500 \\
> & 500 \\
> & 500 \\
> & 500\end{aligned}$} \\
\hline Staphylococcus albus & 40 & 17 & 40 & 40 & 2 & & \\
\hline Haem. strep. group A & 17 & $\mathbf{0}$ & 0 & 0 & 2 & & \\
\hline Enterococci & 13 & $\mathbf{0}$ & 0 & $\mathbf{0}$ & 2 & & \\
\hline $\begin{array}{l}\text { Gram-negative } \\
\text { Proteus sp. }\end{array}$ & 15 & $\mathbf{0}$ & $\mathbf{0}$ & 0 & 2 & \multirow{4}{*}{$\begin{aligned} &> 500 \\
&>500 \\
&>500 \\
& 200-500 \\
&>500 \\
&>500 \\
&>500 \\
&>500\end{aligned}$} & \multirow{4}{*}{$\begin{aligned}> & 500 \\
> & 500 \\
> & 500 \\
& 200-500 \\
> & 500 \\
> & 500 \\
> & 500 \\
> & 500\end{aligned}$} \\
\hline Escherichia & 20 & $\mathbf{0}$ & 0 & 0 & 2 & & \\
\hline Klebsiella & 12 & $\mathbf{0}$ & $\mathbf{0}$ & 0 & 2 & & \\
\hline Pseudomonas pyocyanea & 15 & $\mathbf{0}$ & 0 & 0 & 2 & & \\
\hline
\end{tabular}

Table IV. Sensitivity of Gram-positive and -negative bacteria to clotrinazole

${ }^{1}$ Disc sensitivity: zone of inhibition diameter over $15 \mathrm{~mm}$ round $9 \mathrm{~mm}$ disc.

CHANGES IN SENSITIVITY TO CLOTRIMAZOLE AFTER PASSAGE ON GRADIENT PLATES

These changes are set out in Table $\mathrm{V}$.

\begin{tabular}{llll}
\hline Fungus & $\begin{array}{l}\text { Number } \\
\text { Passages }\end{array}$ & $\begin{array}{l}\text { MIC }(\mu \mathrm{g} / \mathrm{ml}) \text { in Liquid } \\
\text { Medium }\end{array}$ \\
\cline { 2 - 4 } & & $\begin{array}{l}\text { Before } \\
\text { Passage }\end{array}$ & $\begin{array}{l}\text { After } \\
\text { Passage }\end{array}$ \\
\hline Candida albicans & 15 & $0 \cdot 5$ & $1-2$ \\
Candida albicans & 15 & $0 \cdot 2$ & $1-2$ \\
Candida albicans & 15 & $0 \cdot 2-0 \cdot 5$ & $1-2$ \\
Candida albicans & 15 & $0 \cdot 2-0 \cdot 5$ & $0 \cdot 5-1$ \\
Candida pseudo tropicalis & 15 & $0 \cdot 1-0 \cdot 2$ & $0 \cdot 5$ \\
Candida non-albicans & 15 & $0 \cdot 5-1$ & $1-2$ \\
Candida non-albicans & 15 & $0 \cdot 5$ & $1-2$ \\
Candida non-albicans & 15 & $0 \cdot 5-1$ & $1-2$ \\
Cryptococcus neoformans & 15 & $0 \cdot 2-0 \cdot 5$ & $2-5$ \\
Cryptococcus neoformans & 15 & $0 \cdot 5-1$ & $2-5$ \\
Aspergillus fumigatus & 10 & $0 \cdot 2-0 \cdot 5$ & $1-2$ \\
Aspergillus fumigatus & 10 & $1-2$ & $2-5$ \\
Aspergillus fumigatus & 10 & $0 \cdot 5-1$ & $1-2$ \\
Madurella mycetomi & 10 & $0 \cdot 5-1$ & $1-2$ \\
Madurella mycetomi & 10 & $1-2$ & $1-2$ \\
Microsporon audouini & 10 & $0 \cdot 2-0 \cdot 5$ & $0 \cdot 5 \cdot 1$ \\
Trichophyton menta- & & & \\
$\quad \begin{array}{l}\text { grophytes } \\
\text { Trichophyton menta- } \\
\text { grophytes }\end{array}$ & 10 & $0 \cdot 2-0 \cdot 5$ & $1-2$ \\
\hline Table V Changes & 10 & $1-2$ & $2-5$ \\
\hline
\end{tabular}

Table V Changes in sensitivity to clotrimazole after passage

EFFECTS OF SUBINHIBITORY AND INHIBITORY CONCENTRATIONS OF CLOTRIMAZOLE ON FUNGI GROWING IN INFUSION BROTH

\section{Candida spp}

Little physical change was apparent in Candida spores even at cidal drug levels, but they appeared not to produce hyphae; control cultures in drug-free broth grew luxuriant hyphae.

\section{Aspergillus spp}

The conidiophores when fully mature were very small and showed defective sporulation (Figs. 2, 3, and 4). The hyphae became thin and rarefied, and were frequently fragmented. Interference microscopy revealed small segments of living mycelium within the fragmented hyphae; when the fungus was transferred from broth with subinhibitory concentrations of clotrimazole to drug-free broth, fresh outgrowth grew from these live segments (Figs. 5, 6 , and 7).

Similar changes were noted in Trichophyton spp.

\section{ASSAYS ON SERUM AND URINE FROM PATIENTS} RECEIVING CLOTRIMAZOLE

Five infants received $100 \mathrm{mg} / \mathrm{kg} /$ day in six hourly doses of an aqueous suspension of the drug; three of them also had $10 \mathrm{ml}$ of $0.1 \%$ aqueous clotrimazole suspension instilled into a ureteric catheter at eight hourly intervals during the first six days of treatment. A brief summary of the cases is included in Table VI; full clinical details will be reported elsewhere. No clinical, haematological or biochemical side effects were observed.

Clotrimazole was also estimated on five faecal samples from cases 1 and 2; levels of $12,90,90,95$, and $110 \mu \mathrm{g}$ clotrimazole per $\mathrm{g}$ wet faeces were recorded.

Clotrimazole sensitivity tests and assays on serum, urine, and occasionally faeces were made on 


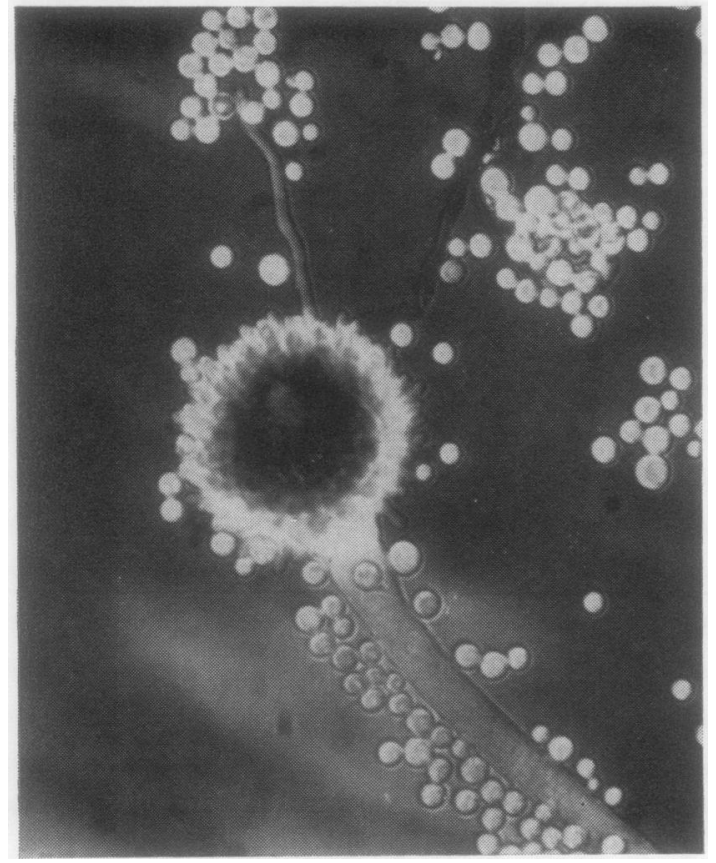

Fig. 2.

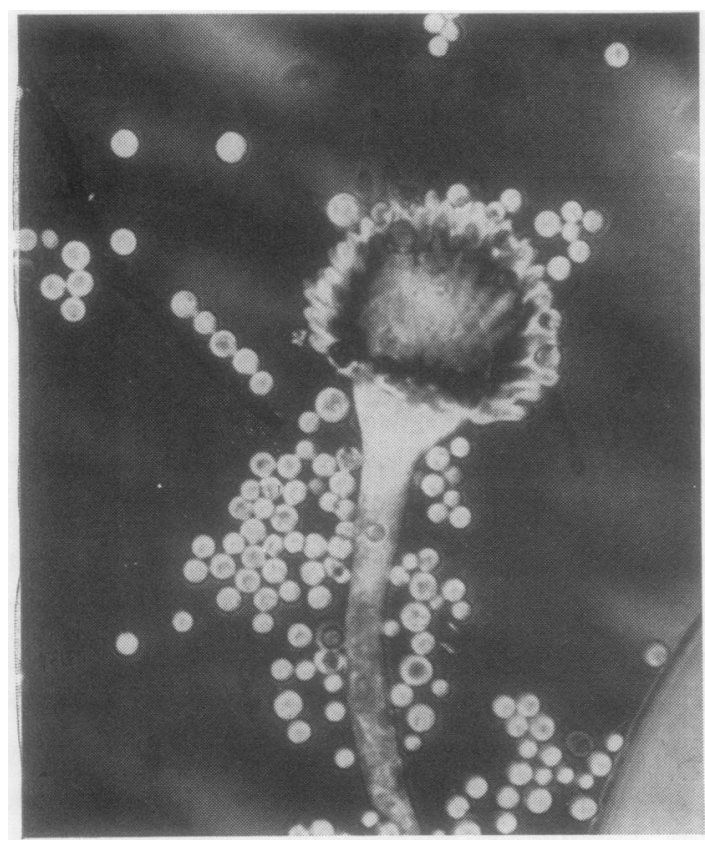

Fig. 3.

Figs. 2 and 3 Mature conidiophores of Aspergillus flavus in drug-free broth

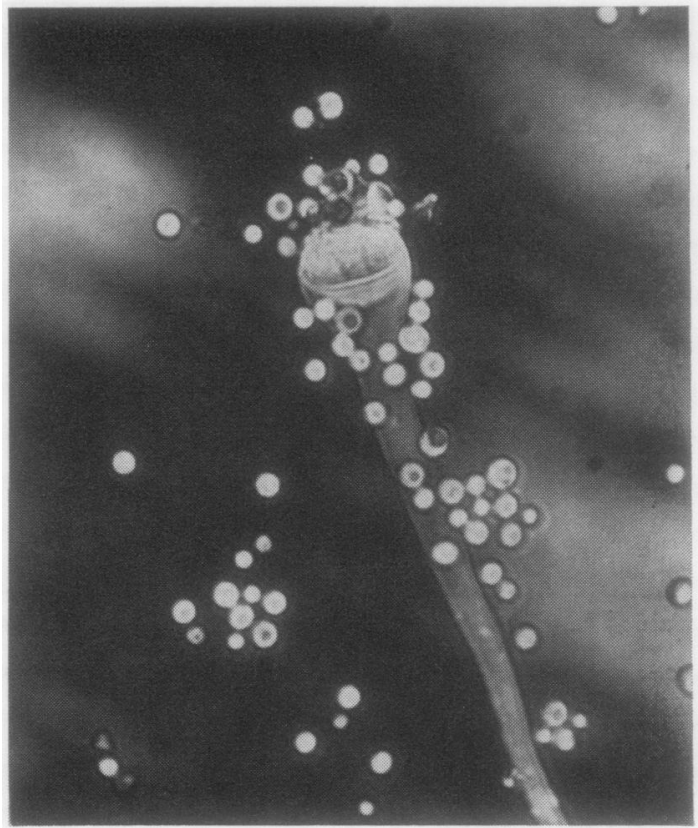

Fig. 4 Conidiophore of Aspergillus flavus in broth containing $1 \mathrm{\mu g} / \mathrm{ml}$ clotrimazole

specimens from 18 patients in other hospitals witl severe candidosis, frequently with accompanying candidaemia; most cases had received renal transplants and some had received cardiac valve replacements. All the strains of Candida required MICs below $1 \mu \mathrm{g} / \mathrm{ml}$, mostly $0 \cdot 1 \mu \mathrm{g} / \mathrm{ml}$, and MCCs below $10 \mu \mathrm{g} / \mathrm{ml}$, all but three below $2 \mu \mathrm{g} / \mathrm{ml}$. Twenty-two serum assays ranged between 0.35 and $0.01 \mu \mathrm{g} / \mathrm{ml}$, and 17 urine levels were estimated between 0.3 and $0.01 \mu \mathrm{g} / \mathrm{ml}$. Two specimens of faeces contained 15 and $100 \mu \mathrm{g} / \mathrm{g}$ wet faeces. The duration of treatment varied between three and 21 days.

Similar studies were made on specimens from 18 cases of lung aspergillosis, includ ing several with aspergilloma, receiving clotrimazole; three patients also had sarcoidosis. Seventeen strains of $A$. fumigatus were examined; 16 had MICs below 1 $\mu \mathrm{g} / \mathrm{ml}$, the other below $2 \mu \mathrm{g} / \mathrm{ml} ; 14$ strains required MCCs below $2 \mu \mathrm{g} / \mathrm{ml}$, one strain $2-5 \mu \mathrm{g}$, one strain 5-10 $\mu \mathrm{g}$, and one $10-20 \mu \mathrm{g} / \mathrm{ml}$. Fifty-four sera were assayed, with levels between 0.4 and $0.01 \mu \mathrm{g} / \mathrm{ml}$ and 38 urine samples had levels between 0.3 and 0.01 $\mu \mathrm{g} / \mathrm{ml}$. Fourteen sputa had clotrimazole concentrations between $0.05 \mu \mathrm{g} / \mathrm{ml}$ and just detectable levels. Several of these patients received treatment for eight to 12 weeks, although where candidosis was associated with terminal renal failure only a short course of therapy was possible. 


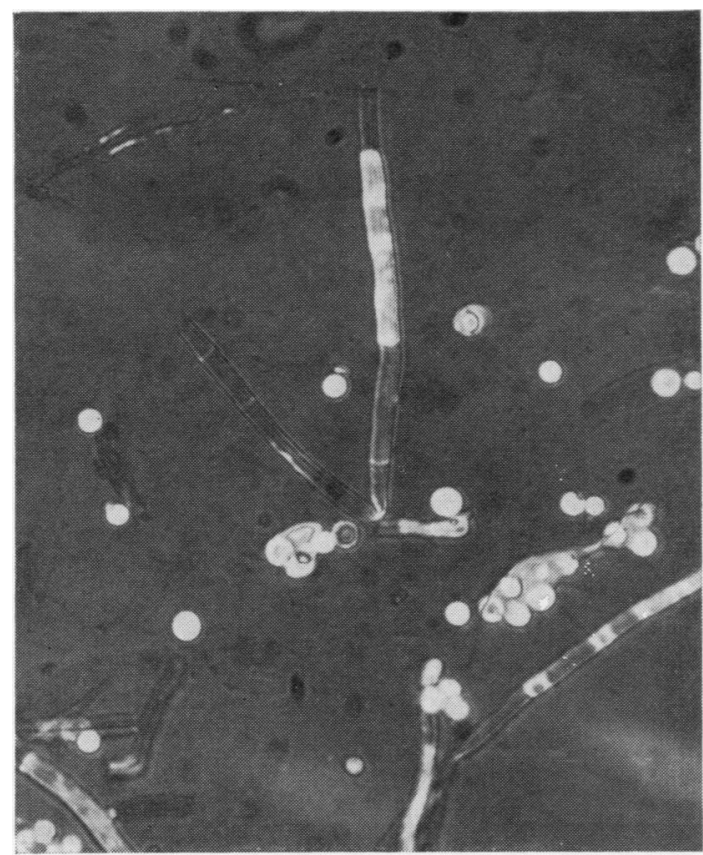

Fig. 5.

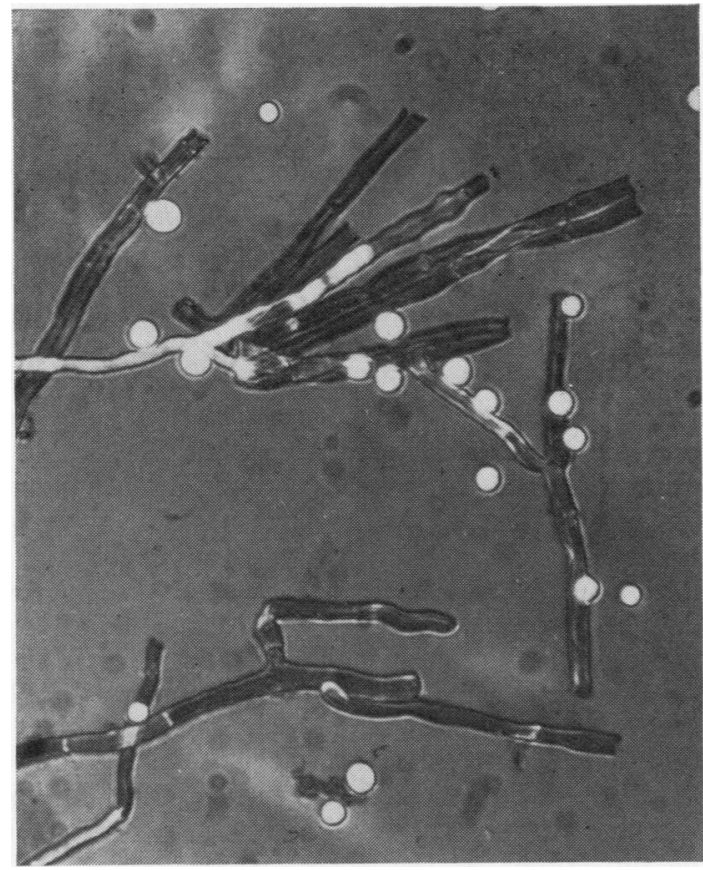

Fig. 6.

Figs. 5 and 6 Fragmented hyphae of Aspergillus flavus grown in broth containing $1 \mu \mathrm{g} / \mathrm{ml}$ clotrimazole

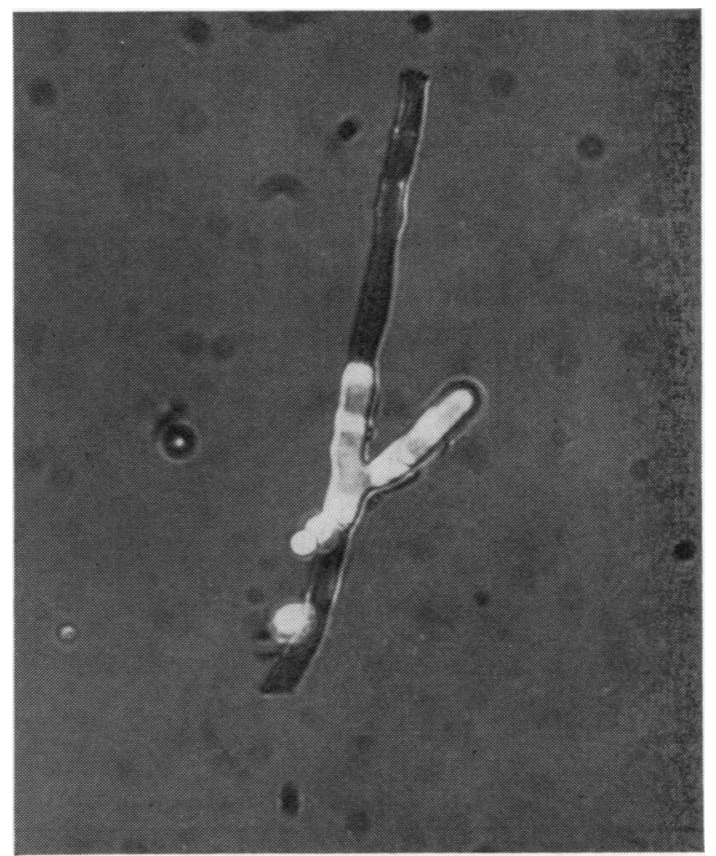

Fig. 7 Fresh outgrowth from segment of living mycelium after transfer to drug-free broth

Clinical and radiological details of these cases may be presented elsewhere; very frequently they were not available to us.

\section{Discussion}

There can be little doubt that clotrimazole has considerable activity in vitro towards the Candida genus, Cryptococcus sp., Aspergillus fumigatus, and the dermatophytes, almost all of which require minimal inhibitory concentrations well below 2 $\mu \mathrm{g} / \mathrm{ml}$. Individual strains of the same species, however, require widely differing inhibitory and cidal levels; the MCC/MIC ratio for single strains varied between 1 and 100 . For this reason it is strongly recommended that the MIC and MCC should be estimated on all initial isolates and on re-isolates where clotrimazole therapy is contemplated, particularly since microbiological assay of drug concentration in biological fluids has revealed such low levels. Rarely does the serum level estimated in terms of antimycotic activity exceed $0.4 \mu \mathrm{g} / \mathrm{ml}$.

Marget and Adam (1971) reported serum levels between 5 and $25 \mu \mathrm{g} / \mathrm{ml}$ in their paediatric cases, values several hundred times those obtained in the present study on similar dosage. The discrepancy is explained by the method of estimation; the procedure 


\begin{tabular}{|c|c|c|c|c|c|c|c|c|c|c|}
\hline \multirow[t]{2}{*}{$\begin{array}{l}\text { Case } \\
\text { No. }\end{array}$} & \multirow[t]{2}{*}{ Sex } & \multirow[t]{2}{*}{ Age } & \multirow[t]{2}{*}{$\begin{array}{l}W t \\
(k g)\end{array}$} & \multirow[t]{2}{*}{ Clinical Details } & \multicolumn{2}{|c|}{$\begin{array}{l}\text { Sensitivity to } \\
\text { Clotrimazole }\end{array}$} & \multirow{2}{*}{$\begin{array}{l}\text { Duration of } \\
\text { Therapy } \\
\text { (days) }\end{array}$} & \multicolumn{2}{|c|}{$\begin{array}{l}\text { Range of Assay Results } \\
(\mu \mathrm{g} / \mathrm{ml})\end{array}$} & \multirow[t]{2}{*}{ Outcome } \\
\hline & & & & & $M I C$ & $M C C$ & & Serum & Urine & \\
\hline 1 & $\mathbf{M}$ & $5 / 12$ & 6 & $\begin{array}{l}\text { Bilateral hydro- } \\
\text { nephrosis, due to pos- } \\
\text { terior urethral valves } \\
\text { Candida in urine and blood }\end{array}$ & $0 \cdot 01$ & $1 \cdot 0$ & $\begin{array}{l}28 \\
\text { plus } \\
\text { instillation }\end{array}$ & $\begin{array}{l}0 \cdot 02-0 \cdot 15 \\
(9 \text { assays) }\end{array}$ & $\begin{array}{l}0 \cdot 05-4 \\
(45 \text { assays) }\end{array}$ & $\begin{array}{l}\text { Urine and blood negative } \\
\text { after nine days } \\
\text { No recurrence }\end{array}$ \\
\hline 2 & $\mathbf{M}$ & $8 / 12$ & 8 & $\begin{array}{l}\text { 'Prune belly' syndrome } \\
\text { Rt kidney absent, } \\
\text { urethral obstruction due } \\
\text { to valves, } C \text {. albicans in } \\
\text { urine and blood }\end{array}$ & 0.11 & $1 \cdot 0$ & 14 & $\begin{array}{l}0.01-0.09 \\
(10 \text { assays) }\end{array}$ & $\begin{array}{l}0.01-0.03 \\
(18 \text { assays) }\end{array}$ & $\begin{array}{l}\text { Urine and blood negative } \\
\text { after six days } \\
\text { No recurrence }\end{array}$ \\
\hline 3 & $\mathbf{F}$ & $6 / 12$ & 5 & $\begin{array}{l}\text { Lumbar meningomyel- } \\
\text { ocele, dilated ureters, } \\
\text { bladder diverticula, } \\
\text { C. albicans in both } \\
\text { kidneys, and in bladder }\end{array}$ & 0.5 & $2 \cdot 5$ & $\begin{array}{l}14 \\
(100 \mathrm{mkd}) \\
\text { then } 14 \\
(150 \mathrm{mkd}) \\
\text { plus } \\
\text { instillation }\end{array}$ & $\begin{array}{l}0 \cdot 01-0.08 \\
(6 \text { assays) }\end{array}$ & $\begin{array}{l}0-0.05 \\
\text { ( } 7 \text { assays) }\end{array}$ & $\begin{array}{l}\text { Urine cultures positive till } \\
\text { increased dose plus } \\
\text { instillation, then negative } \\
16 \text { th day onwards } \\
\text { Infection recurred three } \\
\text { months later }\end{array}$ \\
\hline 4 & $\mathbf{M}$ & $2 / 12$ & 3 & $\begin{array}{l}\text { Left nephroureter- } \\
\text { ectomy transurethral } \\
\text { resection of urethral } \\
\text { valves, } C \text {. albicans in } \\
\text { ureteric urine }\end{array}$ & $0 \cdot 1$ & $1-2$ & 21 & $\begin{array}{l}0.01-0.08 \\
\text { (10 assays) }\end{array}$ & $\begin{array}{l}0.01-0.04 \\
\text { ( } 11 \text { assays) } \\
\text { but no drug } \\
\text { in urine } \\
\text { during last } \\
\text { nine days }\end{array}$ & $\begin{array}{l}\text { Urine cultures remained } \\
\text { positive throughout; } \\
\text { no change in drug } \\
\text { sensitivity } \\
\text { Changed to } 5 \text { FC- } \\
\text { successful }\end{array}$ \\
\hline 5 & $\mathbf{M}$ & $5 / 12$ & 5 & $\begin{array}{l}\text { Nephrectomy, ureteric } \\
\text { implants; unhealed, } \\
\text { untreated suprapubic } \\
\text { catheter track, C. albicans } \\
\text { in urine. Failed } \\
\text { 5-fluorocytosine therapy }\end{array}$ & $1-2$ & $2-5$ & $\begin{array}{l}63 \\
\text { plus } \\
4 \text { days } \\
\text { instillation }\end{array}$ & $\begin{array}{l}0 \cdot 04 \\
\text { ( } 2 \text { assays) }\end{array}$ & $\begin{array}{l}0-0.07 \\
(12 \text { assays })\end{array}$ & $\begin{array}{l}\text { Urine cultures persistently } \\
\text { negative after } 45 \text { days } \\
\text { treatment. } \\
\text { No recurrence }\end{array}$ \\
\hline
\end{tabular}

Table VI Patients treated with clotrimazole

used by Plempel et al (1969) to assay sera from the German cases was photocolorimetric, and did not distinguish between active drug and metabolites. The latter were mainly derivatives belonging to the 2-chlorotritylcarbenol series which appeared in urine and serum during continuous medication with the drug, and it would seem that these metabolites were regarded as microbiologically inactive. It is important to establish the relation between the low active levels and the much higher levels of combined active and inactive imidazole derivatives in body fluids. We are certain that the former is the realistic value in the control of therapy.

Because the levels of active drug in body fluids are insufficient to give fungicidal or fungistatic activity, but are enough to discourage fungal growth and further tissue invasion, the success of clotrimazole as a systemic antimycotic agent probably depends on the maintenance of drug levels in the body for several weeks, although assistance from somatic immune response and surgery where indicated is probably an essential factor. The results of the tests for emergence of strains with increased resistance to clotrimazole after multiple subcultures therefore assume importance; the experiments indicate that no great changes in MIC occur, and suggest that prolonged treatment with the drug will not provoke the emergence of resistant strains in vivo. At no time during therapy have strains of fungi with greatly enhanced resistance been isolated.
Little has been reported on the fate of clotrimazoge $\vec{\varphi}$ after absorption from the intestine, but it see $N$ certain that it is metabolized in the liver (Plempet et al, 1969), and unpublished reports on cases treated in Germany suggest that disruption of hepatic enzyme activity may occur; the drug probably acts with non-specific induction of liver enzymes, and $\frac{Q}{\circ}$ for this reason frequent biochemical monitoring of $\stackrel{2}{\Rightarrow}$ liver function, especially transaminase activity, is $\overrightarrow{0}$ essential. In our series, three observations may reflect the heavy involvement of the liver in clotrimazole metabolism. We found repeatedly that serum levels taken at a constant interval after the previous dose fell as treatment continued beyond two weeks. Secondly, during the later weeks of treatment the six-hour curve of drug concentration in serum $\delta$ became increasingly flat, with a vestigial peak in the third hour, whereas estimations during the first fewo days showed a definite peak at this time. Thirdly, in two children the serum and urine drug levels roseo for a few days after treatment was stopped, and only then subsided rapidly. A further unusual finding iser that there was no concentration of the drug in urine, $N$ in which the clotrimazole content was frequently noN higher than the serum level taken at approximately the same time.

Many thousands of imidazole derivatives are? theoretically possible, and certainly several hundredo have been synthesized and subjecied to in-vitro tests. Three quite different imidazole derivatives haveō 
undergone in-vitro evaluation in these laboratories. Miconazole has about half the activity of clotrimazole over a similar range of fungi but, although clinical trials have been conducted in Belgium with some success on pulmonary candidoses and topical conditions (Brugmans, and van Cutsem, and Thienpont 1970), little is known of its pharmacological fate. Its antibacterial activity was limited to Gram-positive bacteria, and opinions will differ on the value of this particular attribute. Myco-Polycid shows antifungal activity over a wide range, with perhaps one-tenth the activity of clotrimazole, but this is probably sufficient to account for the success of this compound in topical antimycotic therapy; we know of no reports on its systemic use.

Certainly clotrimazole is far from an ideal systemic antimycotic agent; it cannot be given parenterally, it sometimes proves intolerable when given by mouth, and it sometimes disturbs normal liver enzyme activity, which may account in part for the low antimycotic levels detected by us in serum and other body fluids. It is, however, a valuable topical drug, active across a wide fungal spectrum, and it is the only relatively safe drug for the treatment of lung and other deep-seated mycoses caused by Aspergillus fumigatus.

Professor Walter Marget of Munich first introduced this drug to us and we acknowledge most sincerely his kind and valuable help then and at subsequent discussions.

We are grateful to $\mathrm{Mr} \mathrm{H}$. B. Eckstein and Dr D. M. Forrest, consultant surgeons to this hospital, for permission to treat children in their care, and for the support from $\mathrm{Mr} \mathrm{C}$. H. Frankcombe and his staff in our routine Microbiology Laboratories. Cultures and body fluids from patients receiving clotrimazole were kindly sent to us by many clinicians and laboratory workers throughout Great Britain. Lastly, it is a pleasure to record our thanks for the cooperation we have unstintingly received from $\mathrm{Dr}$ H. B. Allen, Mr J. Dixon, and more recently Mr C. Good, FRCS, and the supply of various formulations of clotrimazole from Bayer Pharmaceuticals Ltd.

\section{References}

Andriole, V. T., and Kravetz, H. M. (1962). The use of amphotericin B in man. J. Amer. med. Ass., 180, 269-272.

Brugmans, J. P., van Cutsem, J. M., and Thienpont, D. (1970). Treatment of long-term tinea pedis with miconazole. Arch. Derm., 102,428-432.

Cruickshank, R. (1965). Medical Microbiology, 11 th ed. Livingstone, Edinburgh.

Holt, R. J., and Newman, R. L. (1967). Candida in the faeces of children receiving oral tetracycline and phenoxymethyl penicillin. J. clin. Path., 20, 80-83.

Holt, R. J. (1970). Studies on the broad spectrum antimycotic agent Bay b5097 (Clotrimazole). In Proceedings of the 10th International Congress of Microbiology, Mexico City, p. 149.

Holt, R. J. (1971). Laboratory and clinical studies on antifungal drugs of the imidazole series. (Abstr.). In Proceedings of the VIIth International Congress of Chemotherapy, Prague, Vol. 1, A.4/7.

Lightbown, J. W., and Sulitzeanu, D. (1957). The assay of penicillin in blood-serum using Sarcina lutea. Bull. Wld Hlth Org., 17, 553-567.

Marget, W., and Adam, D. (1971). Bay B5097, a new orally applicable antifungal substance with broad spectrum activity. Acta paediat. scand., 60, 341-345.

Oberste-Lehn, H., Baggesen, I., and Plempel, M. (1969). Erste klinische Erfahrungen bei Systemmykosen mit einem neuen oralen Antimykotikum. Dtsch. med. Wschr., 94, 1365-1367.

Plempel, M., Bartmann, K., Büchel, K. H., and Regel, E. (1969). Experimentelle Befunde über ein neues oral wirksames Antimykotikum mit breiten Wirkungsspektrum. Disch.med. Wschr., 94, 1356-1364.

Szybalski, W. (1952). Gradient plate technique for study of bacterial resistance. Sctence, 116, 46. 